Microbiology and Molecular

Biology Reviews

MICROBIAL

METABOLISM OF

OXALIC ACID

William B. Jakoby and J. V. Bhat 1958. MICROBIAL METABOLISM OF OXALIC ACID. Microbiol. Mol. Biol. Rev. 22(2):75-80.

Updated information and services can be found at:

http://mmbr.asm.org

These include:

CONTENT ALERTS

Receive: RSS Feeds, eTOCs, free email alerts

(when new articles cite this article), more $>>$

Information about commercial reprint orders:

http://journals.asm.org/misc/reprints.dtl

To subscribe to an ASM journal go to:

http://journals.asm.org/subscriptions/

Journals.ASM.org 


\title{
MICROBIAL METABOLISM OF OXALIC ACID
}

\author{
WILLIAM B. JAKOBY ${ }^{1}$ AND J. V. BHAT²
}

Although the synthesis of urea by Wöhler in 1828 is credited with dispelling the notion of vital forces involved in the synthesis of organic chemicals, the first organic compound to be assembled from inorganic matter is the subject of the present review. Legend has it that because of the empirical formula, written as $\mathrm{C}_{2} \mathrm{O}_{3} \cdot \mathrm{H}_{2} \mathrm{O}$ at the time, oxalic acid prepared from cyanogen by Wöhler in 1824 was judged to be "inorganic." More pertinent here is the interest of the microbiologist and biochemist in oxalic acid as the most highly oxidized of organic compounds.

Oxalate enjoys ubiquitous distribution in the animal and plant kingdoms. In humans, oxalic acid and its salts are present in urine, in blood to the extent of $4 \mathrm{mg}$ per cent (1), and in kidney "stones", of which they may form a major constituent (46). Although minute amounts are synthesized by mammals $(2,3)$ it is reasonable to suppose that much of the oxalate of animals originates from the oxalate ingested with plant material. Enormous quantities of oxalate are often found in leaves (4), amounting in one case to 20 per cent of the dry weight of the plant (4). Accumulation of oxalate by fungi, particularly by species of Aspergillus, Penicillium, and Mucor (5), are of such an order that they may be adapted to industrial fermentation for this compound.

Animals appear not to catabolize oxalate appreciably $(2,3,6)$ and, although higher plants as well as mosses do metabolize it to some extent, it would seem that a major portion of oxalate scavenging is left to the bacteria and, possibly, the fungi. Oxalate, however, does not generally accumulate in fertile soil to the extent that its toxic properties (i.e., it is a powerful chelating agent) interfere with plant growth. However, the organisms generally available in laboratory culture collections are not proficient in oxalate oxidation. Indeed, in an exhaustive

1 National Institute of Arthritis and Metabolic Diseases, and National Institute of Dental Research, National Institutes of Health, Public Health Service, U. S. Department of Health, Education and Welfare, Bethesda, Md.

2 Fermentation Technology Laboratory, Indian Institute of Science, Bangalore, India. study of compounds supporting bacterial growth, Den Dooren de Jong (7) and Ayers et al. (8) were unable to obtain growth of a variety of saprophytic bacteria when oxalate was the sole carbon source. Much of the literature pertaining to attempts at demonstrating bacterial utilization of oxalate has been reviewed (9).

To date several organisms have been isolated which are able to grow on a medium containing only inorganic salts, a nitrogen source, and oxalate. These strains have been obtained by the enrichment culture technique from a variety of sources and their routine isolation has been simplified by a technical modification of the enrichment medium (10). Of the organisms obtained, only the following have been characterized to the extent of allowing taxonomic classification: Pseudomonas astragali (11), Pseudomonas oxalaticus (12), Pseudomonas rimaefaciens (13), Pseudomonas extorquens ${ }^{3}$ (14), Vibrio oxaliticus (10), Bacterium oxaliticum (17), and Mycobacterium lacticola (18). Other isolated organisms include unidentified coryneform bacteria (19), pseudomonads (19-21), and several saprophytic mycobacteria (22). Several species of Nocardia $(23,24)$ and Streptomyces $(23,25)$ were able to utilize oxalate as the sole carbon source. Other Streptomyces required supplementation with yeast extract before oxalate utilization was demonstrated (26).

It is of interest that attempts to isolate anaerobes utilizing oxalate have been unsuccessful $(11,21)$ although it has been reported (27) that Pseudomonas aeruginosa will grow on oxalate under anaerobic conditions.

\section{OXALIC ACID CATABOLISM}

Soluble enzyme systems have been demonstrated which catabolize oxalic acid by at least

3 The isolation of Bacillus extorquens by Bassalik (14) represented the first report of an organism able to utilize oxalate as the sole carbon source. Although this strain perished, Janota $(15,16)$ has been able to isolate an organism resembling the original in every respect, which she has preferred to name Pseudomonas extorquens because of its characteristic morphology. 
three routes and involve oxidation, decarboxylation, or activation followed by decarboxylation.

Oxidation. The oxidation of oxalic acid, resulting in the formation of carbon dioxide and hydrogen peroxide (reaction 1) has been found in mosses and in higher plants. Within this limitation a wide spectrum of species

$$
\underset{\mathrm{COOH}}{\mathrm{COOH}}+\mathrm{O}_{2} \rightarrow 2 \mathrm{CO}_{2}+\mathrm{H}_{2} \mathrm{O}_{2}
$$

is capable of carrying out the reaction (28). Peroxide has been identified as the product (29) and the stoichiometry of the reaction was established (30). More recently this work has been confirmed with extracts of spinach (31) and of several mosses (32). This type of reaction is consistent with the suspicion of flavoprotein mediation. Although the moss enzyme has been found to be markedly stimulated by $\mathrm{FMN}^{4}$ or riboflavin but not by FAD (32), rigorous proof of flavin participation as a coenzyme is not available.

Consideration should also be given to the possibility of a pyridine nucleotide-linked oxidation of oxalic acid (reaction 2). Convincing evidence for the existence of such a dehydrogenase is not available. However, mention

$$
\text { (2) } \begin{aligned}
&\left.\right|_{\mathrm{COOH}} ^{\mathrm{COOH}}+\mathrm{DPN}^{+}\left(\mathrm{TPN}^{+}\right) \rightarrow 2 \mathrm{CO}_{2} \\
&+\mathrm{DPN}(\mathrm{TPNH})+\mathrm{H}^{+}
\end{aligned}
$$

is made of the demonstration $(33,34)$ of the reduction of methylene blue when oxalate and plant extracts were incubated anaerobically, a result which could be interpreted as due to the involvement of pyridine nucleotide or of flavin coenzymes. In the case of barley preparations (34) the addition of a yeast kochsaft was found to be necessary for this activity. In one case aerobic oxidation of oxalate with a moss preparation in the presence of cyanide was not found to yield peroxide although the participation of catalase was not completely ruled out (35).

Decarboxylation. The direct decarboxylation of

4 The following abbreviations are employed: FMN, flavin mononucleotide; FAD, flavin adenine dinucleotide; DPN and TPN, di- and triphosphopyridine nucleotides, respectively; DPNH and TPNH, the reduced forms of DPN and TPN, respectively; ThPP, thiaminpyrophosphate; formyl-CoA, acetyl-CoA, oxalyl-CoA, etc., the CoA derivatives of the respective acids. oxalate is thought to be the system active in the white-rot, wood-destroying fungi (36). The categories of white-rot and brown-rot fungi were found to be distinguishable by the accumulation of oxalate by the latter group and the ability to catabolize oxalate by the former (36). The purified decarboxylase from Collyvia veltipes (37) is a stable enzyme, specific for oxalic acid decarboxylation in the reaction shown below:

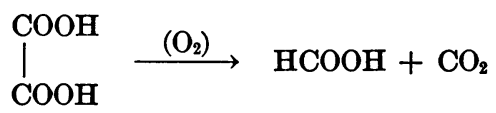

The enzyme is peculiar in that catalytic quantities of oxygen are required for the reaction to proceed although the over-all process does not utilize oxygen stoichiometrically. Oxygen can not be replaced by a variety of compounds, including hydrogen peroxide, quinone, cytochrome $c$, or the flavin and pyridine nucleotides.

Activation and decarboxylation. The only bacterial system described for the utilization of oxalate was found in a pseudomonad and can, in the presence of acetyl-CoA and ThPP, catalyze the conversion described by reaction $7(20)$. The evidence presented suggests that reaction 7 is the summation of reactions 4 to 6 .

$$
\begin{aligned}
\text { oxalate }+ \text { acetyl-CoA } \rightarrow & \text { oxalyl-CoA } \\
& + \text { acetate }
\end{aligned}
$$

oxalyl-CoA $\stackrel{(\mathrm{ThPP})}{\longrightarrow}$ (formyl-CoA)

$$
\text { (formyl-CoA) }+\mathrm{H}_{2} \mathrm{O} \rightarrow \text { formate }+\mathrm{CoA}
$$

$$
\begin{aligned}
& \text { oxalate + acetyl-CoA } \\
& +\mathrm{H}_{2} \mathrm{O} \stackrel{(\text { ThPP })}{\longrightarrow} \text { formate } \\
& +\mathrm{CO}_{2}+\text { acetate }+\mathrm{CoA}
\end{aligned}
$$

Pyridine nucleotides are not directly involved in oxalate decarboxylation. A DPN-specific formic dehydrogenase (reaction 8 ) has, however, been purified

\section{(8) $\mathrm{HCOOH}+\mathrm{DPN}^{+} \rightarrow \mathrm{CO}_{2}+\mathrm{DPNH}+\mathrm{H}^{+}$}

from the same organism (38) and when added to the oxalate system together with DPN will produce two moles of carbon dioxide per mole of oxalate utilized. It is of interest that preliminary experiments ${ }^{5}$ indicate similar requirements for oxalate decarboxylation when Neurospora crassa or baker's yeast preparations are used.

${ }^{B}$ Unpublished results of Y. Yamamura, $O$. Hayaishi, and W. B. Jakoby. 


\section{OXALIC ACID FORMATION}

Since the initial studies of Wehmer with Aspergillus niger (39), the formation of oxalic acid has been assiduously investigated. Because of the large quantities of oxalate accumulated and the availability of methods for their growth under controlled conditions, the fungi have been the experimental organisms of choice. The literature bearing on oxalic acid formation during growth or with mycelial preparations has been summarized in detail by Foster (5) and by Nord (40). Examination of the available information indicates that a great variety of carbon sources is able to give rise to oxalate. Although such data can only be suggestive, this work has led to the proposal of what seem to be two logical pathways for oxalate formation. Reaction 9 involves the cleavage of oxaloacetic acid while reaction 10 depends upon the

(9)<smiles>O=C(O)COC(=O)C(=O)CC(=O)O</smiles>

(10)<smiles>O=CCCCCCC(=O)OC(=O)C(=O)O</smiles>

oxidation of glyoxylic acid.

Formation by cleavage. Reaction 9, which had been previously proposed (41), seems to be operative in extracts obtained from $A$. niger (42). A soluble preparation from this organism produced equimolar quantities of oxalate and acetate per mole of oxaloacetate utilized. Magnesium ions stimulate the reaction somewhat. Under these conditions the substitution of oxalosuccinate for oxaloacetate did not produce oxalate.

A hydrolytic reaction with oxalosuccinate as substrate (reaction 11) should not, however, be dismissed as a possible means of oxalic acid production<smiles>O=C(O)CCOC(=O)C(CC(=O)O)CC(=O)O</smiles>

by other organisms. Nor should the possibility of cleavage by reagents other than water, i.e., phosphate or $\mathrm{CoA}$, be neglected. Indeed an enzyme, thiolase, from a pseudomonad has been described (43) which is active in the formation and scission of $\beta$-ketoadipyl-CoA to form succinyl-CoA and acetyl-CoA (reactions 12 and 13).

(12) $\beta$-ketoadipate + succinyl-COA $\rightarrow$ $\beta$-ketoadipyl-CoA + succinate

(18) $\beta$-ketoadipyl-CoA $+\mathrm{CoA} \rightarrow$ succinyl-CoA + acetyl-CoA

(14) oxaloacetate + succinyl-CoA $\rightarrow$ oxaloacetyl-CoA + succinate

(15) oxaloacetyl-CoA $+\mathrm{CoA} \rightarrow$ oxalyl-CoA + acetyl-CoA

Indirect spectrophotometric evidence indicated that the substitution of oxaloacetate for $\beta$-ketoadipate may give rise to a similar series of reactions (reactions 14 and 15) although neither the products, i.e., oxalyl-CoA and acetyl-CoA, nor the intermediate, i.e., oxaloacetyl-CoA, have been isolated from such a reaction mixture (43). That a compound such as oxalyl-CoA can be formed by a transfer reaction has already been described for another pseudomonad (reaction 4).

Formation by oxidation. Using relatively crude extracts from tobacco leaves, it has been demonstrated (44) that oxalic acid is formed from glyoxylic acid under aerobic conditions. The mechanism of the reaction is not as yet clear because of the heterogeneous protein extract employed but may be similar to

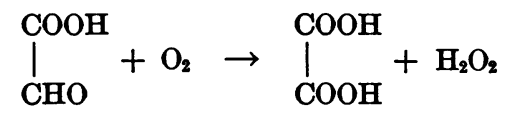

one present in spinach. The latter enzyme (45), a flavoprotein, is active on two $\alpha$-hydroxy acids, glycolic and lactic acids, with the formation of glyoxylic and pyruvic acids, respectively. This specificity need not, of course, apply to the tobacco leaf extracts, which are active with glyoxylic, glycolic, and lactic acids. However, there is no evidence that one enzyme has the specificity to handle all three substrates.

Attempts have been made to obtain systems catalyzing the general reaction described by 
equation 17 , i.e., pyridine nucleotide-

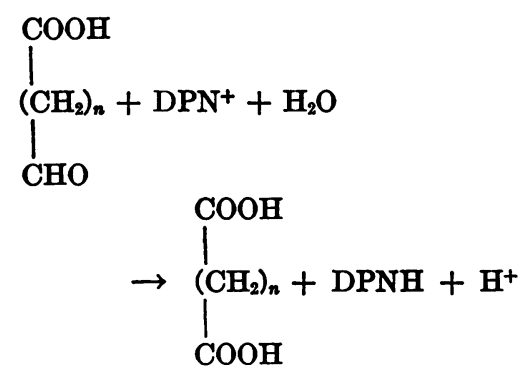

enzymes active in the dehydrogenation of semialdehydes. Such enzymes have recently been obtained from $P$. fluorescens (47), mammalian brain (48), and baker's yeast. ${ }^{6}$ Although the microbial systems are active with succinic semialdehyde where, $n=2$, glyoxylate $(n=0)$ is not utilized. The brain enzyme does use glyoxylate as well as other semialdehydes with the concomitant formation of DPNH. Oxalate, the expected product of brain semialdehyde dehydrogenase action with glyoxylate as substrate, has not yet been isolated and characterized.

\section{DIsCUSSION}

The high state of oxidation of oxalate, requiring the removal of only two electrons for $\mathrm{CO}_{2}$ formation, has led to the suggestion (10) of the possible "autotrophic" nature of organisms able to utilize oxalate as the sole carbon and energy source. Oxalate would be degraded to $\mathrm{CO}_{2}$, thus furnishing energy which would in turn be used for $\mathrm{CO}_{2}$ reduction. With the finding that formate is an intermediate in oxalate oxidation by a pseudomonad another explanation becomes plausible. It has been shown that formate can be oxidized with the formation of DPNH (reaction 8). DPNH, in turn, may be used by the organism as the energy source for adenosine triphosphate formation or more directly for the reduction of another mole of formate. In effect, it is suggested that the pseudomonad utilizes oxalate by decarboxylation followed by the dismutation of formate. It would, then, be formate rather than oxalate which serves the organism as both carbon and energy source. In the case of $V$. oxaliticus, which cannot grow with formate as the sole carbon and energy source (10), an activated formate, as suggested by reaction 5 ,

\footnotetext{
- Unpublished results of W. B. Jakoby and E. M. Scott.
}

may be considered as playing the above described role. However, a system for extensive $\mathrm{CO}_{2}$ fixation by this organism has not been excluded as a possible anabolic pathway.

Plants, on the other hand, appear to handle oxalate by oxidation to $\mathrm{CO}_{2}$. Obviously, plant life is well adapted to $\mathrm{CO}_{2}$ fixation and the oxidation of oxalate may only be in the nature of a "detoxification" reaction.

\section{REFERENCES}

1. Enrico, L. 1953 Ricambio dell'acido ossalico nei basedowiani prima e dopo intervento chirurgico. Arch. sci. med., 25, 112-130.

2. Curtin, C. O'H., and King, C. G. 1955 The metabolism of ascorbic acid-1-C 14 and oxalic acid-1-C $\mathrm{C}^{14}$ in the rat. J. Biol. Chem., 216, 539-548.

3. Weinhouse, S., and Friedmann, B. 1951 Metabolism of labeled 2-carbon acids in the intact rat. J. Biol. Chem., 191, 707-717.

4. Thmmann, K. V., and Bonner, W. D., Jr. 1950 Organic acid metabolism. Ann. Rev. Plant Physiol., 1, 75-108.

5. Foster, J. W. 1949 Chemical activities of the fungi. Academic Press, Inc., New York.

6. Bernard, K. 1954 Isotope als Indikatoren zur Erforschung des Lipidstoffwechsels. Schweiz. med. Wochschr., 84, 506-508.

7. DEN Dooren DE Jong, L. E. 1926 Bijdrage tot de kennis van het Mineralisatieproces. Dissertation, Delft.

8. Afers, S. H., Rupp, P., ANd Johnson, W. T. 1919 A study of the alkali forming bacteria found in milk. U. S. Dept. Agr. Bull. 782, 1-38.

9. Bhat, J. V., and Khambata, S. R. 1955 Microbial decomposition of oxalate. Soc. Biol. Chemists, India. Souvenir, 186-190.

10. Bhat, J. V., and Barker, H. A. 1948 Studies on a new oxalate-decomposing bacterium, Vibrio oxaliticus. J. Bacteriol., 55, 359-368.

11. Khorshed, M., Pavri, M., and Bhat, J. V. 1953 Studies on the microorganisms associated with the leaves of Pongamia glabra vent. Proc. Indian Acad. Sci., Sect. B, 38, 171-178.

12. Khambata, S. R., and Bhat, J. V. 1953 Studies on a new oxalate-decomposing bacterium, Pseudomonas oxalaticus. J. Bacteriol., 66, 505-507.

13. Breed, R. S., Murray, E. G. D., and HitchENs, A. P. 1948 Bergey's manual of determinative bacteriology. 6th ed., p. 123. Williams \& Wilkins Co., Baltimore. 
14. Bassalik, K. 1913 Uber die Verarbeitung der Oxalsäure durch Bacillus extorquens $n$. sp. Jahrb. wiss. Botan., 53, 255-302.

15. Janota, L. 1950 Przebieg zuzywania kwasu s zczawowego przez Pseudomonas extorquens Bassalik, w zaleznosci od poczatkoweg licsby komorek. Med. Doswiadczalna i Mikrobiol., 2, 131-132.

16. JANOTA, L. 1957 Further researches on Pseudomonas extorquens Bassalik. A microorganism utilizing oxalic acid. Acta Soc. Botan. Polon., 26, 207-214.

17. Kнамвата, S. R., and Bhat, J. V. 1953 Bacterium oxaliticum, a new oxalate-decomposing bacterium isolated from the intestine of earthworms. Proc. Indian Acad. Sci., Sect. B, 38, 157-160.

18. Khambata, S. R., and Bhat, J. V. 1955 Decomposition of oxalate by Mycobacterium lacticola isolated from the intestine of earthworms. J. Bacteriol., 69, 227-228.

19. Кнамвата, S. R. 1954 Studies on some microorganisms associated with the intestine of the Indian earthworm. Dissertation, University of Bombay.

20. Jakoby, W. B., OHMURa, E. K., and HAYAISHI, O. 1956 Enzymatic decarboxylation of oxalic acid. J. Biol. Chem., 222, 435-446.

21. Jayasuriya, G. C. N. 1955 The isolation and characteristics of an oxalate-decomposing organism. J. Gen. Microbiol., 12, 419-428.

22. Long, E. R. 1922 The nutrition of acidfast bacteria. Am. Rev. Tuberc., 5, 857869.

23. McCldng, N. M. 1954 The utilization of carbon compounds by Nocardia species. J. Bacteriol., 68, 231-236.

24. MULher, H. 1950 Oxalsäure als Kohlenstoffquelle für Mikroorganismen. Arch. Mikrobiol., 15, 137-148.

25. Starka, J. 1955 Rozkad oxalatu pudnimi mikroorganismy. Preslia, 27, 21-26.

26. Khambata, S. R., and Bhat, J. V. 1954 Decomposition of oxalate by Streptomyces. Nature, 174, 696-697.

27. Robinson, G. L. 1932 The growth of $B$. pyocyaneus in synthetic media. Brit. $\mathrm{J}$. Exptl. Pathol., 13, 310-317.

28. Hodget, S., Mayer, A., and Puantefol, L. 1928 Sur une forme particuliere d'oxydation biologique. II. Ann. physiol. physicochim. biol., 4, 123-128.

29. Hodget, J., Mayge, A., and Planterol, L. 1927 Sur une particuliere d'oxydation biologique. Compt. rend., 185, 304-306.
30. Franke, W., and Hasse, K. 1937 Zur Biologischen Oxydation der Oxalsäure. $Z$. physiol. Chem., 249, 231-255.

31. Finkle, B. J., And Arnon, D. I. 1954 Oxidative decarboxylation of oxalic acid. Physiol. Plantarum, 7, 614-624.

32. Datta, P. K., ANd Meguse, B. J. D. 1955 Moss oxalic acid oxidase-a flavoprotein. Biochim. et Biophys. Acta, 17, 602-603.

33. Thunberg, T. 1928 Zur Kenntnis der enzymatischen Oxydation der Oxalsäure durch Pflanzensamen. Skand. Arch. Physiol., 54, 6-16.

34. Fodor, A., and Frankenthal, L. 1930 Uber das Dehydrierungsvermogen von Getreidesames in Anwesenheit von Pflanzensäure und Purinsubstanzen als Wasserstoffdonatoren. Biochem. Z., 225, 417-425.

35. Nigkerk-Blom, C. J. 1946 Notes on the oxidation of oxalic acid by mosses. Proc. Ned. Akad. v. Wetensch., Amsterdam, 49, 1096-1100.

36. Shimazono, H. 1955 Oxalic acid decarboxylase, a new enzyme from the mycelium of wood destroying fungi. J. Biochem., Japan, 42, 321-340.

37. Shimazono, H., and Hayaishi, O. 1957 Enzymatic decarboxylation of oxalic acid. J. Biol. Chem., 227, 151-159.

38. JAковт, W. B. 1956 Enzymatic decarboxylation of oxalic acid. Federation Proc., 15, 282.

39. WeHMER, C. 1911 Chemical activity of the Aspergillaceae. In Technical mycology, Vol. 2, pp. 259-277. Edited by F. Lafar. Charles Griffin and Co., Ltd., London, England.

40. NoRd, F. F., AND Weiss, S. 1951 Yeast and mold fermentations. In The enzymes, Vol. 2, Part 1, pp. 684-790. Edited by J. B. Sumner, and $\mathbf{K}$. Myrbäck. Academic Press, Inc., New York.

41. LYNen, F., AND LYNen, F. 1948 Die bildung von Oxalsäure durch Aspergillus niger. Ann., 560, 149-162.

42. Hayaishi, O., Shimazono, H., Katagiri, M., and Sarto, Y. 1956 Enzymatic formation of oxalate and acetate from oxaloacetate. J. Am. Chem. Soc., 78, 5126.

43. Katagiri, M., and Hayaishi, O. 1957 Enzymatic degradation of $\beta$-ketoadipic acid. J. Biol. Chem., 228, 439-448.

44. Kenten, R. H., and Mann, P. J. G. 1952 Hydrogen peroxide formation in oxydations catalysed by plant $\alpha$-hydroxyacid oxidase. Biochem. J., 62, 130-134.

45. ZeLitch, I., AND OCHOA, S. 1953 Glycolic acid oxidase. J. Biol. Chem., 201, 707-718. 
46. Archer, H. E., Dormer, A. E., Scowen, E. F., AND WATts, R. W. E. 1958 The aetiology of primary hyperoxaluria. Brit. Med. J., I, 175-181.

47. Scott, E. M., AND JAKOBY, W. B. 1958 Pyrrolidine metabolism: Soluble $\gamma$-aminobutyric transaminase and semialdehyde dehydrogenase. Science, in press.

48. Albers, R. W., and Salvador, R. A. 1958 Succinic semialdehyde oxidation by a soluble dehydrogenase from brain. Science, in press. 